\title{
"REVERSE CENTRIFUGAL MOVEMENT": Reading Liminality at the Shrinescaph
}

\author{
Syamsul Asri \\ Fajar University, Makassar; Universitas Gadjah Mada (UGM), \\ Yogyakarta, Indonesia \\ E-mail: syamsulasri14@gmail.com \\ Heddy Shri Ahimsa Putra \\ Universitas Gadjah Mada (UGM), Yogyakarta, Indonesia \\ E-mail: ahimsa_putra@yahoo.com \\ Albertus Bagus Laksana \\ Sanata Dharma University, Yogyakarta, Indonesia \\ E-mail: bagus.laksana@gmail.com
}

\begin{abstract}
The main objective of this paper is to explain the nature and dynamics of solidarity and kindness that being shown in arbain walk, an annual Shi'i pilgrimage where noticeable presence of non-Muslims are observed. Coming from different religious and ethnic backgrounds, these lovers of Imam Husain are united by Imam Husain's barakah in one hand and epic hospitality of Iraqi people for Imam Husain's millions of devotee in other hand. The paper argues that this is an elaborated form of liminality, as emerge and envelope the pilgrims in their shrine-related religious activity, cordially affected by its shrine centered pilgrimage, namely Imam Husain's shrine, in which shrine's materiality and its multilayered intellectual and spiritual narrativity determines the form and intensity of pilgrim's comradeship that being sensed. Reverse centrifugal movement is a dynamics through which Imam Husain's shrinescape shapes the form and intensity of mutual friendship that emerge during this bigger than haij annual rite.
\end{abstract}

Keywords: Liminality; Reverse Centrifugal Movement; Global Husaini; Shrinescape.

Article history: Received: 15 November 2020; Revised: 24 December 2020; Accapted: 08 January 2021; Available online: 01 March 2021

\section{How to cite this article:}

Asri, Syamsul, Heddy Shri Ahimsa Putra, and Albertus Bagus Laksana. "Reverse Centrifugal Movement': Reading Liminality at the Shrinescape". Religio: Jumal Studi Agama-agama 11, no. 1 (2021): 83-100. https://doi.org/10.15642/religio.v11i1.1649. 


\section{Introduction}

There is no other event that had played a significant role for Shi'i Muslim community in shaping their identity and collectivity more than the tragic event of Karbala. Before Karbala, there is no significant difference between Sunni Muslim and Shia Muslim, even though there already existed a division in Muslim's politico body, namely the reference point for authority, whether it goes to Ali or Muawiyah. But Karbala marked Shiism as a unique social group in terms of it is signifying rituals and collective memories to differentiate Shia from Sunni Muslims. This division thus becomes the solid foundation for further consolidation, both in discourse and performativity. ${ }^{1}$

For Shi'i Muslim, the tragic, traumatic and haunted event of Imam Husain's massacre along with his family and loyal friends in 10 Muharram $61 \mathrm{H}$ (October 10, $680 \mathrm{CE}$ ) which took place in Karbala, southern Iraq nowadays, has been seen as the turning point for the emerge of conscience both as community or personal Muslim. The beloved grandson of Prophet Muhammad along with his 72 male companion and his family slain by 70.000 Yazid bin Muawwiyah's soldier in the desert after being left without water and food supply for 3 days. He was beheaded and his head, which was always being kissed by his grandfather, The God's Prophet, carried upon a lance, marched from Karbala to Yazid Bin Muawwiyah's court in Damascus, along with Imam Husain' female family members and friends, including his survived son, Imam Ali bin Husain. ${ }^{2}$

At forty (Arabic: arbain) days after Imam Husain's assassination, there came to Karbala the old Prophet's companion, Jabir Ibn Abdullah al-Anshari (who was blind thus accompanied by Atiyya Ibn Sa'ad) to mourn the loss of the Prophet's family, to mourn the incapacity in defending Imam Husain's right against powerful oppressor, and to vow alliance to Imam Husain's cause and to symbolically distance themselves from Yazid's throne. ${ }^{3}$ Abdullah's

\footnotetext{
1 Yitzhak Nakash, "An Attempt to Trace the Origin of the Rituals of Ashura", Die Welt des Islams no. 33, Brill, Leiden, (January 1993): 161.

2 Khalid Sindawi, “The Image Of Husayn Ibn 'Alī In 'Maqātil' Literature," Quaderni di Studi Arabi 20/2 (2003): 79-104 and Sindawi's analysis in his The Cult of the Euphrates and Its Significance among the Imami Shi'i, Der Islam Bd. Online journal, Walter de Gruyter, (Maret 2004): 249-269.

3 Annemarie Schimmel's notion about interreligious and intercultural significances of number 40 is instrumental here. Schimmel explained that number 40 is signifying
} 
arrival in Karbala coincided with the coming of the captive female family members of Husain and Husain's son Ali Bin Husain who bring Imam Husain's head to be reunited with his body. Ali Bin Husain, since the tragic previous 40 days remain in Yazid's imprisonment. Their loss and sorrow mourning promulgated in the ritual of arbain, a Shia religious ritual in the beginning, but nowadays becomes the locus of global hospitality that symbolized for global resistance against hostility and oppression.

Imam Husain's martyrdom regains its global importance thanks to arbain walk, an annual shi'i riyarah event done by walking $75 \mathrm{~km}$ long route from Najaf to Karbala, along the route of which epic hospitality is being practiced for the comfort of Imam Husain's devotee that coming from around the world. If Imam Husain's martyrdom previously exist in revolutionary and spiritual imaginary of world leaders and mystics, arbain walk opens up a new path to convey Imam Husain's legacy, in the sense that arbain walk enacts non-Shi' is as participants in this bigger than bajj rite. This interreligious presence facilitates arbain walk as an arena for meaningful interreligious encounters. Those non-Shi'is that participated in three days walking from Najaf to Karbala are comprising of what I call global Husaini, emerge as the result of dynamic encounters in shrinescape of Imam Husain. Without this dynamics of shrinescape, global Husaini will be only a scattered presence of non-Shi'is in communal pockets of Shi'i adherents around the world commemorating Imam Husain's martyrdom outside Iraq.

The presence of non-Muslims in arbain walk whose being attracted to participate by Imam Husain's suffering and struggle, the enactment of epic hospitality by Iraqi people for waves of Imam Husain's devotees, and Imam Husain's physical and spiritual landscape, all conjure and form what scholars called shrinescape. Explaining the nature and dynamics of this shrinescape is the purpose of this study.

Developing Jo-Ann Gross's understanding of the term, shrinescape used to be understood as culmination of interactions between shrine's physical landscape, material architecture and interpretive practices that form shrine's narrativity that consist of text,

both the completion and perfection in-universe. 40 marks the union of borders in order for arriving another entity. Please see Annemarie Schimmel, The Mystery of Numbers, (Oxford: Oxford University Press, 1993): 245-253. 
reader and interpretation (meaning) all gravitating around the shrine. Critics have shown that Gross's notion of the term embedded in fixity of the shrine and its living surrounding.

The primer example of such fixity is her abandonment of power relations and power struggles that enveloped almost all major shrines but also being reflected by these shrines. Therefore, for me, I take shrinescape as denoting to the creative dialectics between shrine materiality, living doctrine \& narrative and process of immediate structural \& cultural underpinnings that shape and reshape the ways in which the shrine perceived by its congregation. ${ }^{4}$

Here in this modified definition, shrinescape perpetuates the character of flux and flow of the shrine, because shrine is understood not only as relics of the past but more importantly presence of sociopolitical dynamics that marking the contemporary for anticipating peculiar thus specific face of the future. What matter the most here is shrine as an arena but also field for power relations and economic struggles to enact the meaning of the past for contemporary audience in hope for winning the coming days, dominantly done through carefully curated of certain narrative and interpretations surrounding it.

\section{Liminality and Global Husain in Arbain Walk}

For more than fourteen centuries, Imam Husain's martyrdom in Karbala (present day Iraq), already being the object of commemoration of his faithful devotees around the world. Shi' is marks their asyura, the name of this Karbala event, as not only an annually important event but also made it as personal and communal anchor for evaluation for better engagement with Islamic values. Forty days after asyura comes arbain, also an annual event commemorating Imam Husain's legacies, mainly done by walking from several points of departure (such as Imam Ali's shrine in Najaf, Imam Kazdhim's shrine in Northern Baghdad) towards Imam Husain's shrine in Karbala.

After Saddam Husain downfall in 2003 due to USA invasion, however, arbain as solely Shi'i religious event gradually transforms to

\footnotetext{
4 Jo-Ann Gross, "The "Shrinescape" and Narrative Tradition of Khoja Ishaq Khuttalani" in Saintly Spheres and Islamic Landscapes: Emplacements of Spiritual Power across Time and Place, ed. Daphna Ephrat, Ethel Sara Wolper, and Paolo G. Pinto, (Leiden: BRILL, 2020): 149.
} 
become arbain walk. Reflected from the name that comprise of two distict words, arbain walk is arbain but perceived and exercised by global participants for global audiences, hence the walk as an English word fittingly attached to the word arbain. Arbain walk is mainly done by Shi'is and non-Shi'is alike by walking for three days approximately from Imam Ali's shrine in Najaf to Imam Husain's shrine in Karbala, annually around 20 Safar in Islamic lunar calendar.

Small in number but important in role is the presence of Catholic, Protestant, Orthodox Christian, Presbyterian, Hindu, Kejawen in arbain walk. Walking the route along with their co-lovers of Imam Husain, these non-Shi'is called themselves as Husaini, means someone that being touch and transformed by Imam Husain's martyrdom specifically and Karbala event generally.

I call them global Husaini since they are coming from around the world but also more importantly, these non-Shi'is that find Imam Husain's suffering attractive as universal value enabled to be presence physically in Karbala by larger process of world glocalisation. ${ }^{5}$ Both in terms of material (such as transportation facilities from and to Iraq) and sociopolitical preconditions (such as downfall of saddam Husain and the rise \& defeat of ISIS/ISIL) and ideo-theological preconditions (messianic tone of Imam Husain's martyrdom that grounded and disseminate through multilayers of textualities and networks of interpreters) are global in nature.

In arbain walk, it is a common tread for Husaini to reflect his whole life journey during and after walking from Najaf to Karbala. In Oregon based Pastor John Shouck's words:

"It gave me the opportunity for self-reflection, what is my life about, where do I stand, for whom do I speak. I met a man from India and we walked together for about 90 minutes. I don't remember his name but we talked about everything from religion to politics to life, it was a breath of fresh air to be able to have conversations about things that matter with someone from the other side of the world. It was one of many gifts I received on this road to Karbala as we have been making this vlog continuously. We have been thinking that or looking around that everyone is walking in one direction which is towards Karbala. It is towards Imam Hussain and I think it's very symbolic and metaphorical that even in our lives, the

5 Roland Robertson, European Glocalization in Global Context (Hampshire: Pelgrave McMillan, 2014): 16. 
duration that we are in this world, we all need to be walking in one direction, which is in our belief which is my job which is to be free of this world and be with Imam Husain and all the prophets, and be but with God. And the way to do that is to have that singular focus in one direction towards the truth."

Here we are not dealing with common form of universal identity where universality is embraced because it is detached from particular identities. We are dealing here with self that is holescontaining frontier, always in constant encounter, engagement and dialogue state with other selves in reverse centrifugal movement. This kind of walking within walk facilitates the identity construction with more large capacity to embrace difference ("I met a man from India, from another side of the world") in harmonious solidarity ("everyone is walking in one direction which is towards Karbala. It is towards Imam Hussain") even if it is in non-egalitarian form. ${ }^{7}$

The meaning of identity exercised in global stage of ziyarah such as arbain walk is featured of universality that emerges not from detachment from any particulars but from constitutive feature of particulars as always in movement, primarily movement that facilitating the encounters between self and others. ${ }^{8}$ Genuine and workable common ground is best suited as the aim of such encounters. In the case of arbain walk, Imam Husain's barakah and its massage of justice as practicing love in public space, seen as encompassing common ground.

One of the major pitfall of universality is that it is faceless, nowhere to be found concretely. ${ }^{9}$ Everywhere we see only particulars, universal is abstracted category resulted from some kind effort to identify. Hence it is faceless. It speaks to no one, particularly. This is not at all the case that I reject universality. But only, as I mentioned,

${ }^{6}$ John Shuck \& Josh Townsley, For Love of Hussain (A.S.), directed by John Shuck, March 2019, video documentary, 42:14-43:12, https://www.youtube.com/watch?v=8vovB33NRtw\&t=1437s.

${ }^{7}$ Ismail Fajrie Alatas, "Pilgrimage and Network Formation in Two Contemporary B Alaw Hawl in Central Java." Journal of Islamic Studies 25, no. 3 (September 1, 2014): 138-9.

8 Kádár, Dániel Z. "Identity Formation in Ritual Interaction." International Review of Pragmatics 7, no. 2 (January 1, 2015): 57-9; Darius Liutikas, "The Manifestation of Values and Identity in Travelling: The Social Engagement of Pilgrimage," Tourism Management Perspectives 24 (October 2017): 217-24.

9 Eugene Eung Chun Park's respond for my working paper at 2018 IASACT, CUHK, unpublished. 
that universality must take account on particularity thus it is reach in transitory \& heuristic state, in moving along particulars who encounter continuously other particulars. Here universal is active embodiment of particulars. It is grasped by reversed centripetal movement stirred by affective and effective encounter. Every encounter between particulars will spark a kind of liminality, a state of oneself being interrupted by itself being reflected from other self, from which an affective seizure of connectivity towards others is formed.

Victor Turner's communitas and liminality occupy central tenet of global Husaini identity. Solidarity, compassion, driven by the same purpose and value (justice, self-sacrifice i.e. suffering as redemptive quality), sense of comrade-ness along the route of Najaf and Karbala, all are featuring a global devotees of Imam Husain worldview. They come to Karbala, embrace Imam Husain's barakah and mawakib (semi-permanent building, usually tent that being erected for welcoming arbain walk pilgrims) managers's unconditioned hospitality, only to experience the nature of loosening previous structural and formal self-identification. In a fleeting moment, their solid selfidentifying effort confronted by the surplus of solidarity, in the form of barakah of Imam Husain and hospitality provided by mawkib managers, continuously shaking the foundational function of social and ideological preference. ${ }^{10}$

\section{Reverse Centrifugal Movement}

The constant demand for justice practice exercised critically upon oneself is the tenet of global Husaini's attraction for Imam Husain. Realized as the vehicle cum content for divine justice that transcends formal and institutionalized religions, Imam Husain's martyrdom offers for Husaini nothing less than the core value of being religious; to submit to no one other than the Truth, and this is the dictum of divine and humane justice. Not only placing human and the truth in its proper place, this is also actively requiring human freedom from any indignity and violence that may be fallen on her

10 Turner, Victor. Dramas, Fields, and Metaphors: Symbolic Action in Human Society. Reprint edition edition. (Ithaca, NY: Cornell University Press, 1975): 19-20; The Ritual Process: Structure and Anti-Structure. The Lewis Henry Morgan lectures 1966. (New York: Aldine de Gruyter, 1995): 49-53; Turner, Victor, Edith Turner, and Deborah Ross. Image and Pilgrimage in Christian Culture. Revised ed. edition. (New York: Columbia University Press, 2011); 21-8. 
shoulder. ${ }^{11}$ In this very sense, Imam Husain's embodiment of justice also attract non-religious persons, because his struggle put emphasis on the matter of human freedom as the most basic ideals. ${ }^{12}$

The utmost perfect form of such act is found in the epic hospitality being practiced in arbain walk. It is the tenet expression of not only Imam Husain's barakah but also an expression of justice practice in a robust sense since giving and providing kindness to others in arbain walk, almost always complete strangers, is an act of placing the others in its proper, just and adequate place. The others are placed, by subject offering hospitality, in dignity, love, caring, protection, seen naturally as humane condition for humanity. ${ }^{13}$

Hospitality in arbain walk also signals justice in complementary ways, in the sense that in front of others and their otherness, the one and only justice act is self-annihilation for the sake of the other. It is uneasy and dangerous act, but nonetheless it gives an opportunity to free oneself from oneself thus able to move beyond oneself and embrace the universe/other/truth, a genuine gesture of Husaini practice. $^{14}$

When mawakib managers, usually Iraqi Shi'i or Sunni, welcome and embrace waves of stranger, bow down for them, and clean up their shoes or massage their feet or provide water for these dusty walkers, instantly without sufficient verbal introduction (and of course without naming the name or mentioning religious affiliation), then practiced hospitality, here, could be seen as an effort of "reversed centripetal movement" in which a core Islamic value in regards of stranger when practiced effectively enabling the emergence of cosmopolitan and universal value and ethics.

As Saroja Dorairajoo argued in regards of halalan and tayyiban dialectics, the more it is Islamic (tayyiban is more demanding

11 Ahlulbayt TV, Reverend Dr. Malkhas Songulashvili, from Georgia, Visits Karbala for Arbaeen, 2018, https://www.youtube.com/watch?v=14XWqwULZao\&t=114s.

12 William Sturman Sax, Johannes Quack, and Jan Weinhold, eds., The Problem of Ritual Efficacy, Oxford Ritual Studies (Oxford; New York: Oxford University Press, 2010): 4-11.

13 "UNESCO - Provision of Services and Hospitality during the Arba'in Visitation," https://ich.unesco.org/en/RL/provision-of-services-and-hospitality-during-thearba-in-visitation-01474? $\log$ out $=1$.

${ }^{14}$ Christopher Paul Clohessy, Half of My Heart: The Narratives of Zaynab, Daughter of Alî (Gorgias Press, LLC, 2020), p. 3-5; Father Christopher Clohessy: "Interpreting the Life of Lady Zainab,” 2020, Video Clip, 2:14 https://www.youtube.com/watch?v=-NCno_IPtPM\&t=41s. 
categorically than balalan) the more it is universal thus embracing and embraced by multiple others. ${ }^{15}$ As an exemplary case here to arbain walk, is the notion of halalan and tayyibah in Islamic legal discourse, where halalan being perceived as heavily related to Muslim per se while tayyiban (whice requires more higher standard than just halalan) being perceived as related to a cosmopolitan and universal aspect regarding quality of culinary and every day practices related to food, cloth and building. Here, even if tayyiban is more than halalan or more Islamic than balalan but at the same time it is also more embracing and is embraced by others because tayyiban meet with cosmopolitan cum universal standard.

I am coming up with similar conclusion that the more ziyarah being Islamic, the more it will be embraced by and embrace others. It seems to me, at this preliminary stage, that universality emerges not in a detached universal form but from constitutive feature of particulars as always in movement to reach and also being reached by others. ${ }^{16}$

The same thing is observationally grasped in arbain walk's hospitality; rooted in Islamic (or Islamized) value and practice, giving kindness to strangers, sometimes unconditionally, enabling a crucial dialectic happens; particular value universalized not because of detachment process from its root, but because of deepening effort to radicalizing ("digging to the deepest root") its demanding actualization.

Imam Husain's barakah and justice practice embodied in epic hospitality of arbain walk charms countless devotees to come to Karbala, without first and foremost have to be a Shi'i. It is crucial to remember, again, that after all his male family and companion have been defeated, when Imam Husain is finally stand as an alone combatant against his enemies, he is remarkably calling out, "bal min naashirin yansurny?" literally means "is there any helper helping me?" Imam Husain is actually addressing his call to everybody from that day until the end of the world. When dealing with Imam Husain's massacre in Karbala, either one is with Imam Husain or with his killers. Sectarian and religious bordering means next to nothing. The thing that matter the most is justice, understood as truth relation of

\footnotetext{
15 Saroja Dorairajoo, 2018 IASACT Working Paper, Hospitality and Restaurant Culture in Hui Country; Some Insights on Inter-ethnic Dining in Ningxia, CCC-CUHK, unpublished, p. 5-11.

16 Hubert J. M. Hermans, Thorsten Gieser ed., Handbook Of Dialogical Self Theory, (Cambridge: Cambridge University Press, 2014): 81-6.
} 
oneself with everything else in the cosmos. In front of " $\mathrm{bal}$ min naashirin yansurny?" the only just answer is "Labbayka Yaa Husain [here I come forward for You O Husain]", even if the voice answering is shaking, since it is the only right answer. It is justice.

I am not arguing here that religious affiliation and life of devotion is not important. It really is. As Father Malkhas Songulashvili, a priest from Georgia, emphasize, global Husaini as a mark of self and communal identification does not mean as a process of Shi'itization or Islamization nor it is a brutal transcendentalization of religions in price of particular/peculiar uniqueness of every religion, but as accepting the difference, in itself is a candid act of justice. ${ }^{17}$ Nevertheless Imam Husain's massage on sacrifice, suffering, justice and fighting against injustice echoed in others cultural and religious traditions. Of course Imam Husain's syahadah is Islamic, but if it is being given a chance to become a moment of reversed centripetal movement, as it is deserved based on exhaustive narrative accounts by Karbala survivors, ${ }^{18}$ then Imam Husain syahadah embracing and embraced by multiple others.

Imam Husain's sacrifice and suffering echoes in certain Christian worldview, his chivalry and dignity echoes in certain Brahmanic and Tantric subjects, ${ }^{19}$ his enduring spirit for fighting until the last blood drop against tyranny echoes in anticolonial leaders whom sometimes are secular. The notion of reversed centripetal movement allows Imam Husain's ideals simultaneously Islamic but, and more importantly precisely because of this Islamic feature, it is thus located in other's imaginative matrixes.

Moments of reversed centripetal movement in regards of Imam Husain's martyrdom and legacy are located coherently in Husaini practices of justice which particularly expressed and embodied in form of epic and unconditional hospitality being accomplished during arbain walk. As a particular value and action, giving kindness unconditionally for stranger getting through Iraqi's land and homes is a genuine act of Islamic principle of 'adab, but the moment this action extended in practice as a perfected form of one taking care of other

\footnotetext{
17 Ahlulbayt TV, Reverend Dr. Malkhas Songulashvili, from Georgia, Visits Karbala for Arbaeen.

${ }^{18}$ Clohessy, Half of My Heart, 20-3.

19 Shri Acharya PramodKrishnam. Interfaith Webinar: The Real "Beauty" Seen in Arbaeen without Religious Boundaries, 2020, Conference Video, 99:02-114:19 https: / /www.youtube.com/watch?v=6btaNx4vBZE\&t $=8 \mathrm{~s}$.
} 
beyond formal identification (language, religious affiliation, nationality, ethnicity), then it is became more Islamic and at the same time more humanistic.

This is in line of what I already identified as reversed centripetal movement, understanding every particular as continuously in movement, en route, in and upon herself caused by endless effective and affective contacts with other than herself. For her, to find universality is always as the matter of embodiment and practice of self-positioning and counter positioning. ${ }^{20}$ Thus universality is not always out there in the vacuum of action and interaction between particulars, but also here and now in the realm of embodiment, precisely because every embodiment is a universal in motion, en route, in movement, as always it is. To argue that universal also in movement, and not as an unmoving reality embraced and embracing all, is to acknowledge that all is moving thus universe and universal is expanding to be able to hold all particular. ${ }^{21}$

As of Imam Husain's barakah, spring forward from his martyrdom, is a particularity bounded by peculiar time and space. But this barakah, as every other particular, is always in the moving condition. In fact, movement is her fourth essential feature (as also length, width, and volume). This movement primarily caused, and in turn causing, by encounter of this specific barakah with other than herself, such as hope and fear, but also other singular and particular barakah(s).

When these encounters happen, the barakah of Imam Husain become embodied in embodiment of barakah in the route, in the specific routes toward endless self-expanding of barakah in order to be affectively and effectively embrace all other particular. Imam Husain's barakah is universal one, embraced and embracing multiple religious subjectivities, but this barakah become universal primarily because it is exhaustively moving to encounter others, thus happens to self-expanding successfully, at least as visible in arbain walk. Epic expression, celebration and embodiment of this universal barakab found in arbain walk denotes to the matter that Imam Husain's barakah deeply entrenched in Islamic and 7 century Arabian zeitgeist,

${ }^{20}$ Hubert J. M. Hermans, Dialogical Self Theory: Positioning And Counter-Positioning In A Globalizing Society (Cambridge University Press, 2010): 30-1; Gieser and Hermans, "Handbook of Dialogical Self Theory", 8-13.

21 Idris Samawi Hamid, "Shaykh Ahmad al-Ahsa'I" in Philosophy in Qajar Iran, ed. Reza Pourjavady (Leiden: BRILL, 2018): 40-51. 
but it is moving to face other's face, hope, fear, that eventually this barakah embracing and being embraced by these others. ${ }^{22}$

Here again I would like to consider the applicability of a set of concepts that specifically rooted in Islamic worldview but expressing universality without abandoning any kind of embodiment. Let me recall the dialectics of halalan - tayyiban once more; categorically tayyiban refers to set of belief and practice that is more demanding in comparison than halalan as set of belief and practice. The daunting question offered by two decades of research in area such as hotel and culinary industry posed as like this; why food and services that fulfil the categorization of tayyiban are embraced by Muslim and nonMuslim alike, while halalan category just slightly received by Muslim consumers? ${ }^{23}$

The answer of this question is very well known at least in services industry; tayyiban food and services has meet the challenge of contemporary clean, healthy, green and sustainable zeitgeist of consumption, values that significantly also underscored by Islamic faith, while halalan locked in linguistically embroiled in Muslim only practices. We observe, here in the case of tayyiban-related services, that the more one category of religion, belief, and faith exposed to itself more exhaustively, then the more it become universal in the sense it is welcomed and embraced by other's practices.

Regarding the presence of non-Muslim/Shi'i in arbain walk, another pragmatic aspect emerge as one of possible interpretation about the nature of arbain walk as interreligious ziyarah. Arbain walk obviously demonstrated the relevance of religions and its affective \& effective efficacies in contemporary inter-subjective imagination. ${ }^{24}$ Practiced epic hospitality in unconditional gesture towards 25 millions of strangers for almost 4 weeks clearly demonstrated the actual and material of religious ideals. Acceptance, solidarity, dignity, respect, care, truthfulness that embedded in religious systemic social value, even though expressed differently, becomes customary in Najaf to Karbala route annually. It is like social paradise embodied in reachable manner, even though in fleeting sense. It is openly inviting all

\footnotetext{
22 Shri Acharya PramodKrishnam in Interfaith Webinar.

23 Ahmad Jamal, Kevin Griffin, and Razaq Raj, Islamic Tourism: Management of Travel Destinations (CABI, 2018): 18-25; C. Michael Hall and Girish Prayag, The Routledge Handbook of Halal Hospitality and Islamic Tourism (Routledge, 2019): 198-203.

${ }^{24}$ Charles Tweed. Crossing and Dwelling; A Theory of Religion, (Cambridge: Harvard University Press, 2009): 110-1.
} 
religious adherents to come and taste this accomplished ideals, as a contrary gesture to only textual and historical religious ideals.

The notion of reverse centripetal movement as a metaphor to portray the encounter among Husaini from multi subjectivities is made possible because each Husaini sincerely and continue going more and more deeper into herself, spiritually and pedagogically speaking, thus she embrace the universal inside his own self, make her capable of communicating, relating and embracing others.

Out of concern for Islamization or even Shi'itization upon others especially Christian whose presence was strong in Damascus and surrounding Iraq, I perceive that the underlying message of this event is the centrifugal character of suffering and mourning it promulgated. Either this unnamed Christian Priest converted to Islam or not, either the mosque now holds the stone where Imam Husain's head was laid was a church or not, one thing emerge and go on as embodiment practice of interreligious encounter; from that moment when the Priest redeem Imam Husain's head from the killers, concrete alliance between religious based care subjectivities formed against predatory power holders whose religion is nothing more than a deceiving mask.

At this point it will be beneficial to address, once more, the fit fall of universalism as concerning for "faceless no one"25. It is argued that universalism is too abstract thus distancing itself from genuine concern of concrete experience in daily life. Rather than engage in universalism, better we aim for the face to face and frontier encounter for making temporary and mutually beneficial interest as the core feature of social life. Talking universalism is meaningless when no one universal thing can unite different interest found in different subjectivities.

This is a strong argument, actually. Based on pragmatic reasoning it is almost impossible to counter back the notion of "faceless no one" as the beneficiary of universalism. But another route could be emerged if focus is swiched, from diametrical opposition between universal and particular to reversed centrifugal consideration where particular moving deeper into itself and eventually will be meet the others, not because the others is already in

${ }_{25}$ My personal exchange with IASACT 2018 mentor Eugene Eung-Chun Park, a biblical scholar at Redlands University during IASACT Program in CCC-CUHK June-July 2018. 
the self, but because the more one becoming itself the more one embracing the others.

One parallel example from Islamic ethics will be illuminate the point. In relation between halalan and tayyiban cullinary, tayyiban occupies the more demanding aspects of halalan. If halalan concerns with the minimum condition that must be meet in order to please syariah presuppositions, then tayyiban is a metrix of evaluation that going deeper and larger dealing with what is called "the best practice for people and planet". All tayyiban must be halalan but not all halalan is tayyiban. McDonald fried chicken is halalan but since it is lack of healthy measurement towards individual, societal and environmental interest, than it is not tayyiban. ${ }^{26}$ As we could glean from this parallel example, the more a Muslim become a Muslim, the more she capable to embracing and embraced by the others. This is what I call the reverse centrifugal movement; embracing others by perpetually going to the centre of the self.

Another important aspect of this definition of self as momentary trace of reverse centrifugal movement is it is heavily invested in seeing self as movement in such ways that self is gained, sustained and developed through strategically calculated movement, such as found in rite and pilgrimage/ziyarah, as embodied practice of meeting, engaging and affronting others in dialogical nature. By moving internally and externally as described earlier in form of reverse centrifugal 'mechanism", self not only become aware and obvious to itself but also participate in making other self becomes known, even if this knowledge and identification take place only momentarily before being supplanted by another deeper movement. ${ }^{27}$

There is also another vocabulary for the global semantic of global Husain. This vocabulary is not a historical/archival account nor a narrative account, but forms of testimony that found scattered around the globe, which testify abundantly to the recognition of the significance even the crucial role played by the figure of Imam Husain. Usually but not limited to political leaders and men of letter as the sources of these testimony, the remarkable feature of it is they belong to neither Islam religion nor even, sometimes, to established

\footnotetext{
26 Saroja Dorairajoo, "Hospitality and Restaurant Culture in Hui Country; Some Insights on Inter-ethnic Dining in Ningxia: 6-11.

27 Hubert Hermans, Dialogical Self Theory: Positioning and Counter-Positioning In A Globalizing Society, Reprint edition (Cambridge: Cambridge University Press, 2012): $39-42$.
} 
world religion. The only legit term to point them out is global Husaini, which portray their immutable loyal affection towards Imam Husain's cause but also to the fact that they are already transformed, both intellectually and faithfully, by the Karbala event e.g. Karbala as lens by/with it they see and embrace the self and the world at large. Again, here we are dealing not with faceless universalism but rather with reversed centrifugal identity construction with Karbala event as a catharsis point inviting different subjectivities to go deeper into their self.

As could be glean from John Shuck's reflection upon his walking in 2018 arbain, the Pastor find himself enveloped with in larger wave of movement towards the truth, as embodied in Imam Husain's martyrdom. Here self-identification as an active part of bigger movement only possible because the walk itself, both as physical walk and walking within walk. Movement provides this Pastor direction; point of beginning, tracks of moving and point of destination, all in all simultaneously physical and beyond physical.

Again, here we are not dealing with common form of universal identity where universality is embraced because it is detached from particular identities. We are dealing here with self that is holescontaining frontier, always in constant encounter, engagement and dialogue state with other selves in reverse centrifugal movement. This kind of walking within walk facilitates the identity construction with more large capacity to embrace difference ("I met a man from India, from another side of the world") in harmonious solidarity ("everyone is walking in one direction which is towards Karbala. It is towards Imam Hussain") even if it is in non-egalitarian form. ${ }^{28}$

This set of discourse of movement guides my theoretical stance that identity formation in global stage of ziyarab such as arbain walk has legitimation because it paves the way to see that identity, both as ascribed and ethical bases, ${ }^{29}$ could be seen as moving entity in flow and flux therefore capable to reconcile apparent contradiction found in identity-related discourse such as primordial versus modern, purposive versus incidental, ascribed versus ethical. ${ }^{30}$

28 Alatas, "Pilgrimage and Network Formation in Two Contemporary B Alaw Hawl in Central Java.": 138-9.

${ }^{29}$ Anthony Elliott, ed., Routledge Handbook of Identity Studies, Routledge International Handbooks (Abingdon, Oxon ; New York, NY: Routledge, 2011): 7-14.

30 Andrew Dawson and Nigel Rapport, eds., Migrants of Identity: Perceptions of "Home" in a World of Movement, First Edition edition (Oxford, UK; New York: Berg 
The meaning of identity exercised in global stage of ziyarah such as arbain walk is featured of universality that emerges not from detachment from any particulars but from constitutive feature of particulars as always in movement, primarily movement that facilitating the encounters between self and others. ${ }^{31}$ Genuine and workable common ground is best suited as the aim of such encounters. In the case of arbain walk, Imam Husain's barakah and its massage of justice as practicing love in public space, seen as encompassing common ground.

\section{Conclusion}

Reverse centrifugal movement, as coinage in this study, refers to the dynamics found in Imam Husain's shrinescape. It is a description for emblematic feature of liminality that being present among, thus enveloping, arbain walk participants. Imam Husain's barakah, Iraqi genuine act of hospitality and materiality and narrativity of Imam Husain's shrine, all are comprised of this shrinescape, that meaningfully provide, facilitate and channel an anchored sense of solidarity, comradeship, togetherness that embraced by arbain walk pilgrims.

This liminality occurred in arbain walk through reverse centrifugal movement, concluded as oneself is moving and going toward her inner self in order to meet and encounter the others/universes/Truth. It is a description for how arbain walk pilgrims come to their shared state of liminality, but also Iraq people's capacity for exercising epic hospitality for millions of stranger, and basing all, it is a name I give for oneself ability to meet others without losing herself. Labbayka yaa Husain is an act of answering a primordial call that coming from inside one's self. []

\section{References}

Publishers, 1998): 44-6; Jason T. Lamoreaux, "Social Identity, Boundary Breaking, and Ritual: Saul's Recruitment on the Road to Damascus," Biblical Theology Bulletin: Journal of Bible and Culture 38, no. 3 (August 2008): 122-34.

31 Kádár, "Identity Formation in Ritual Interaction", p. 57-9; Darius Liutikas, "The Manifestation of Values and Identity in Travelling: The Social Engagement of Pilgrimage," Tourism Management Perspectives 24 (October 2017): 217-24. 
Alatas, Ismail Fajrie. "Pilgrimage and Network Formation in Two Contemporary B Alaw Hawl in Central Java." Journal of Islamic Studies 25, no. 3, September 1, 2014.

Clohessy, Christopher Paul. Half of My Heart: The Narratives of Zaynab, Daughter of Alî. LLC: Gorgias Press, 2020.

Dawson, Andrew. and Rapport, Nigel eds., Migrants of Identity: Perceptions of "Home" in a World of Movement, First Edition edition. Oxford, New York: Berg Publishers, 1998.

Dorairajoo, Saroja. 2018 IASACT Working Paper, Hospitality and Restaurant Culture in Hui Country; Some Insights on Inter-ethnic Dining in Ningxia. Hongkong-CUHK, unpublished.

Elliott, Anthony. ed., Routledge Handbook of Identity Studies. New York: Routledge, 2011.

Gross, Jo-Ann. "The "Shrinescape" and Narrative Tradition of Khoja Ishaq Khuttalani" in Saintly Spheres and Islamic Landscapes: Emplacements of Spiritual Power across Time and Place edited by Daphna Ephrat, Ethel Sara Wolper, and Paolo G. Pinto. Leiden: BRILL, 2020.

Hall, C. Michael and Prayag, Girish. The Routledge Handbook of Halal Hospitality and Islamic Tourism, Routledge, 2019.

Hermans, Hubert J. M. Dialogical Self Theory: Positioning And CounterPositioning In A Globalizing Society. Cambridge: Cambridge University Press, 2010.

Hamid, Idris Samawi. "Shaykh Ahmad al-Ahsa'i" in Philosophy in Qajar Iran (edited by Reza Pourjavady). Leiden: BRILL, 2018.

Jamal, Ahmad, Griffin, Kevin and Raj, Razaq. Islamic Tourism: Management of Travel Destinations. CABI, 2018.

Kádár, Dániel Z. "Identity Formation in Ritual Interaction." International Review of Pragmatics 7, no. 2, January 1, 2015.

Lamoreaux, Jason T. "Social Identity, Boundary Breaking, and Ritual: Saul's Recruitment on the Road to Damascus." Biblical Theology Bulletin: Journal of Bible and Culture, 38, no. 3, August, 2008.

Liutikas, Darius. "The Manifestation of Values and Identity in Travelling: The Social Engagement of Pilgrimage." Tourism Management Perspectives, 24, October, 2017.

Nakash, Yitzhak. "An Attempt to Trace the Origin of the Rituals of Ashura." Die Welt des Islams, no. 33, Brill, January 1993.

Robertson, Roland. European Glocalization in Global Context. Hampshire: Pelgrave McMillan, 2014. 
Sax, William Sturman, Quack, Johannes, and Weinhold, Jan (eds.). The Problem of Ritual Efficacy. New York: Oxford University Press, 2010.

Schimmel, Annemarie. The Mystery of Numbers. Oxford: Oxford University Press, 1993.

Sindawi, Khalid. "The Image of Ḥusayn Ibn 'Alī In 'Maqātil' Literature." Quaderni di Studi Arabi 20/2, 2003.

----. "The Cult of the Euphrates and Its Significance among the Imami Shi'i." Der Islam Bd. Online journal, Walter de Gruyter, 2004.

Turner, Victor. Dramas, Fields, and Metaphors: Symbolic Action in Human Society. Ithaca, NY: Cornell University Press, 1975.

-----. The Ritual Process: Structure and Anti-Structure: The Lewis Henry Morgan lectures 1966. New York: Aldine de Gruyter, 1995.

Turner, Victor, et al. Image and Pilgrimage in Christian Culture: Revised Edition. New York: Columbia University Press, 2011.

Tweed, Charles. Crossing and Dwelling; A Theory of Religion. Cambridge: Harvard University Press, 2009. 